\title{
PENGARUH KEPUASAN KERJA DAN BUDAYA ORGANISASI TERHADAP KOMITMEN ORGANISASIONAL DAN ORGANIZATIONAL CITIZENSHIP BEHAVIOR PERAWAT
}

\author{
I Gede Aryana Mahayasa( ${ }^{(1)}$ \\ Desak Ketut Sintaasih ${ }^{(2)}$ \\ Made Surya Putra ${ }^{(3)}$ \\ ${ }^{(1)}$ Fakultas Ekonomi Universitas Hindu Indonesia, Bali, Indonesia \\ ${ }^{(2),(3)}$ Fakultas Ekonomi dan Bisnis Universitas Udayana, Bali, Indonesia \\ email: aryanamahayasa@yahoo.com
}

\begin{abstract}
ABSTRAK
Tujuan penelitian ini untuk menganalisis pengaruh budaya organisasional dan kepuasan kerja karyawan terhadap komitmen organisasional dan OCB perawat di rumah sakit umum swasta tipe C di Kota Denpasar. Penelitian bersifat kausalitas untuk memberikan penjelasan dan pemahaman terhadap hubungan antara variabel budaya organisasional dan kepuasan kerja dengan variabel komitmen organisasional dan OCB. Populasi penelitian adalah perawat rumah sakit umum swasta tipe $C$ yang ada di Kota Denpasar dengan jumlah responden sebanyak 85 orang perawat. Teknik penentuan sampel dilakukan dengan teknik penyamplingan proporsional dan pemilihan sampel pada masing-masing rumah sakit dengan metode undian. Instrumen penelitian menggunakan kuesioner dan metode analisis dengan menggunakan analisis deskriptif dan analisis inferensial dengan analisis Structural Equation Model-Partial Least Square (SEM-PLS). Hasil penelitian menunjukkan bahwa budaya organisasional berpengaruh positif dan signifikan terhadap komitmen organisasional dan OCB, kepuasan kerja karyawan berpengaruh positif dan signifikan terhadap komitmen organisasional dan OCB. Implikasi penelitian yaitu, perlunya komitmen yang kuat dari manajemen rumah sakit untuk mampu menerapkan nilai-nilai budaya organisasi yang bisa diterima oleh karyawan serta memperhatikan faktor-faktor pembentuk kepuasan kerja karyawan. Saran penelitian yaitu, perluasan orientasi penelitian pada lingkup industri dan organisasi yang lebih luas untuk memperoleh hasil yang lebih komprehensif.
\end{abstract}

Kata kunci: kepuasan kerja, budaya organisasional, komitmen organisasional, OCB

\begin{abstract}
The purpose of this study was to analyze the influence of organizational culture and employee satisfaction to organizational commitment and organizational citizenship behavior $(O C B)$ of nurses at private general hospitals type $C$ in Denpasar. This study was a causality research to provide an explanation and understanding of the relationship between the variables of organizational culture and job satisfaction to variable of organizational commitment and $O C B$. The population in this study was nurses of private general hospitals type $C$ in the city of Denpasar, with number of respondents were 85 nurses. Sampling technique conducted with a proportional sampling technique and sample selection in each hospital conducted with a lottery method. The research instrument used questionnaires and methods of analysis used descriptive analysis and inferential analysis with the analysis of Structural Equation Model-Partial Least Square (PLS-SEM). The results showed that the organizational culture had a positive and significant influence on organizational commitment and $O C B$, employee satisfaction had a positive and significant influence on organizational commitment and $O C B$. Implications of this research namely the need for a strong commitment from hospital management to be able to apply the values of the organizational culture that can be received by the employee and with regard to the factors forming employee satisfaction. Research's suggestions namely expansion within the scope of the industry and the wider organization of research orientation to obtain more comprehensive results.
\end{abstract}

Keywords: job satisfaction, organizational culture, organizational commitment, $O C B$

\section{PENDAHULUAN}

Persaingan di berbagai sektor perekonomian yang meningkat yang dipicu oleh globalisasi mengharuskan pelaku industri menyesuaikan perilaku, metode, dan strategi usahanya agar mampu mempertahankan eksistensi dan keberlanjutan usaha. Perilaku yang memberikan kebebasan bertindak yang bukan merupakan bagian dari pekerjaan formal karyawan, namun mampu memberikan kontribusi untuk lingkungan pekerjaan sosial dan psikologis, disebut perilaku kewarganegaraan. Organisasi yang sukses membutuhkan karyawan yang mampu melakukan pekerjaan melampaui harapan organisasi itu sendiri. 
Karyawan yang terlibat dalam perilaku peran ekstra yang baik, akan menunjukkan perilaku seperti membantu rekan kerja yang lain dalam tim mereka, rela untuk bekerja ekstra dan bersedia melakukan hal-hal yang tidak tercantum secara formal dalam deskripsi pekerjaan, serta menghindari konflik yang tidak perlu (Robbins et al., 2013). Karyawan yang memiliki kemampuan untuk melanjutkan atau memenuhi berbagai tanggung jawab yang sebelumnya dilakukan oleh rekan kerja dan bersedia untuk memperluas tanggung jawab mereka dan berkomitmen penuh untuk upaya restrukturisasi rumah sakit serta mampu terus mengerahkan perilaku diskresioner yang melebihi persyaratan peran formal mereka dan meningkatkan fungsi rumah sakit secara umum, dikatakan sebagai karyawan yang memiliki Organizational Citizenship Behavior (OCB) yang baik (Bolon, 1997).

Organizational citizenship behavior secara signifikan dipengaruhi oleh kepuasan kerja karyawan dan akan semakin meningkat dengan semakin tingginya pengaruh moderasi komitmen tim (Foote and Tang, 2008). Chahal dan Mehta (2011) mengungkapkan dalam hasil penelitiannya bahwa beberapa faktor yang dapat mempengaruhi OCB dari persepektif komprehensif adalah kejelasan peran (role clarity), kepemimpinan, komitmen organisasional, keadilan organisasional dan sifat-sifat individu (individual traits), yang akan sangat mempengaruhi kinerja organisasi. Hutahayan et al. (2013) dalam studinya pada karyawan industri manufaktur menyatakan bahwa beberapa faktor yang berpengaruh secara langsung pada OCB karyawan adalah adanya penghargaan (rewards) dan budaya organisasional dan secara tidak langsung dipengaruhi oleh kepemimpinan transformasional melalui budaya organisasional.

Industri rumah sakit sebagai sebuah bentuk organisasi pelayanan jasa kesehatan dewasa ini harus mulai berhadapan dengan kontrol yang sangat ketat terhadap kondisi keuangan organisasi, kualitas pelayanan serta persaingan yang ketat dengan berbagai industri rumah sakit yang lainnya. Kualitas pelayanan sebuah rumah sakit salah satunya sangat dipengaruhi oleh pelayanan yang diberikan oleh para perawatnya dalam menjalankan tugas dan kewajibannya memberikan pelayanan yang maksimal kepada pasien.

Permasalahan yang saat ini sering dihadapi oleh rumah sakit dalam usaha untuk mencapai keberhasilan serta memberikan pelayanan yang optimal adalah masalah hubungan antara sumber daya manusia dengan organisasi, yang berkaitan dengan tuntutan-tuntutan baik dari organisasi maupun sumber daya manusia itu sendiri. Salah satu masalah yang menonjol adalah perilaku karyawan yang kurang menguntungkan bagi organisasi. Fenomena yang terjadi akhir-akhir ini adalah kurangnya kesadaran karyawan rumah sakit khususnya para perawat untuk mampu melakukan kegiatan maupun tugas yang tidak secara formal diatur dalam deskripsi pekerjaan mereka. Kesediaan mereka untuk mengambil alih pekerjaan maupun menggantikan peranan rekan kerjanya yang pada saat yang bersamaan sedang melakukan pekerjaan yang lain juga masih sangat rendah. Kondisi di tempat penelitian ini juga didukung oleh keterangan salah seorang pimpinan di salah satu rumah sakit umum swasta tersebut yang dijadikan narasumber dalam observasi ini. Kondisi ini mengakibatkan menurunnya kualitas pelayanan rumah sakit.

Studi yang menjelaskan pengaruh dan peranan OCB pada industri rumah sakit sampai saat ini masih terbatas. Hubungan antara komitmen organisasional, budaya organisasional, kepuasan kerja dan OCB juga belum banyak diteliti.

Penelitian ini bertujuan untuk menganalisis pengaruh budaya organisasional dan kepuasan kerja terhadap komitmen organisasional dan OCB perawat. Kerangka konseptual digunakan untuk menjelaskan rangkaian hubungan antara variabel bebas kepuasan kerja dan budaya organisasional terhadap variabel terikat komitmen organisasional dan OCB perawat.

\section{KAJIAN PUSTAKA}

Huang et al. (2012) mengemukakan tiga kategori perilaku pekerja, yaitu: (a) berpartisipasi, terikat dan berada dalam suatu organisasi; (b) harus menyelesaikan suatu pekerjaan dan bertindak sesuai dengan prinsip-prinsip yang diatur oleh organisasi; serta (c) melakukan aktivitas yang inovatif dan spontan melebihi persepsi perannya dalam organisasi. Kategori terakhirlah yang sering disebut sebagai OCB atau the extra-role behavior (Huang et al., 2012). Menurut Organ (1988), OCB didefinisikan sebagai perilaku individu yang bersifat bebas (discretionary), yang tidak secara langsung atau eksplisit mendapat penghargaan dari sistem imbalan formal, dan yang secara keseluruhan mendorong keefektifan fungsi-fungsi organisasi. Organizational citizenship behavior mengacu pada konstruk dari extra-role behavior (ERB), yang didefinisikan sebagai perilaku yang menguntungkan organisasi dan atau berniat untuk menguntungkan organisasi yang langsung dan mengarah pada peran pengharapan (Robbins et al., 2013). Organ (1988) 
mengidentifikasi OCB ke dalam lima dimensi yaitu altruism, courtesy, civic virtue, conscientiousness dan sportsmanship.

Hofstede (1990) menyatakan bahwa budaya melibatkan nilai (values), di mana sistem nilai merupakan inti dari budaya, nilai-nilai akan meliputi konsep menyeluruh dari symbol, heroes, dan ritual. Luthans (1998) mendefinisikan bahwa budaya organisasional merupakan norma-norma dan nilainilai yang mengarahkan perilaku anggota organisasi, sehingga setiap anggota akan berperilaku sesuai dengan budaya yang berlaku, agar diterima oleh lingkungannya. Schein (2009) mengemukakan teori bahwa budaya organisasi adalah nilai-nilai dan perilaku orang-orang yang dianggap sebagai alat mengarah ke keberhasilan pencapaian tujuan organisasi umum, yang dapat ditemukan dalam tiga tingkatan, yaitu a) tingkatan asumsi, yaitu, asumsi dasar dimana budaya diterima begitu saja sebagai reaksi yang bermula dari nilai-nilai yang didukung, b) nilai, dan c) artefak, dimana budaya bersifat kasat mata namun sering kali tidak dapat diartikan. Model budaya Denison (1990) menghadirkan saling keterkaitan antara budaya organisasi, praktekpraktek manajemen, kinerja dan efektifitas, dan model ini mampu menjelaskan pentingnya hubungan praktik-praktik manajemen dengan asumsi dasar dan kepercayaan dalam menilai efektivitas budaya organisasi, yang memiliki dampak yang mendalam pada kinerja karyawan yang dapat menyebabkan peningkatan dalam produktivitas dan meningkatkan kinerja organisasi (Shahzad et al., 2012). Empat ciri budaya organisasi yang menjadi dimensi dalam kerangka Denison (1990) yaitu involvement (keterlibatan), consistency (konsistensi), adaptability (kemampuan beradaptasi), mission (misi).

Teori utama tentang kepuasan kerja yang sering diadopsi dalam studi-studi tentang kepuasan kerja adalah Teori Dua Faktor dari Herzberg (Robbins et al., 2013). Herzberg et al. (1959) membagi kebutuhan karyawan menjadi dua yaitu, hygiene dan motivator, dimana faktor-faktor hygiene memuaskan karyawan dalam kondisi tertentu seperti pengawasan, hubungan interpersonal, kondisi kerja fisik, gaji, tunjangan, dan lain-lain, sedangkan yang menjadi faktor motivator seperti prestasi karyawan, tanggung jawab serta perkembangan hasil kerja. Menurut Locke (1969), kepuasan kerja, yang merupakan salah satu hal yang paling banyak dipelajari dalam literatur dan studistudi yang relevan, dapat didefinisikan sebagai suatu keadaan emosi menyenangkan yang dihasilkan dari penilaian pekerjaan seseorang sebagai pencapaian atau fasilitas prestasi terhadap nilai-nilai pekerjaan seseorang. Levy and Montmarquette (2004) menyatakan bahwa kepuasan kerja menggambarkan perasaan pekerja yang didasari atas pengalaman kerjanya. Azeem (2010) and Robbins et. al. (2013) mengungkapkan lima komponen pengukur kepuasan kerja yaitu pembayaran (pay), pekerjaan (job), kesempatan promosi (promotion opportunities), atasan (supervisor), rekan kerja (co-worker).

Komitmen organisasional umumnya didefinisikan sebagai ketertarikan karyawan serta hubungan seorang dengan organisasi (Huang et al., 2012). Menurut Tolentino (2013), komitmen mengacu pada dedikasi seseorang kepada orang, pekerjaan atau organisasi yang tercermin dalam niat seseorang untuk bertekun dalam suatu tindakan. Allen and Meyer (1990) menyatakan dan percaya bahwa komitmen organisasi yang kuat menyebabkan karyawan untuk bekerja lebih keras untuk mencapai tujuan organisasi. Robbins et al. (2013) mendefinisikan komitmen organisasional sebagai suatu keadaan di mana karyawan teridentifikasi dengan organisasi tertentu dan tujuannya, dan berkeinginan untuk mempertahankan keanggotaan dalam organisasi. Meyer and Allen (1990; 1991) mengembangkan konsep komitmen organisasional dengan mengidentifikasi tiga dimensi penting dari komitmen karyawan yaitu komitmen afektif (affective comitment), komitmen berkelanjutan (continuance commitment) dan komitmen normatif (normative commiment). Kerangka konseptual penelitian adalah seperti dalam Gambar 1.

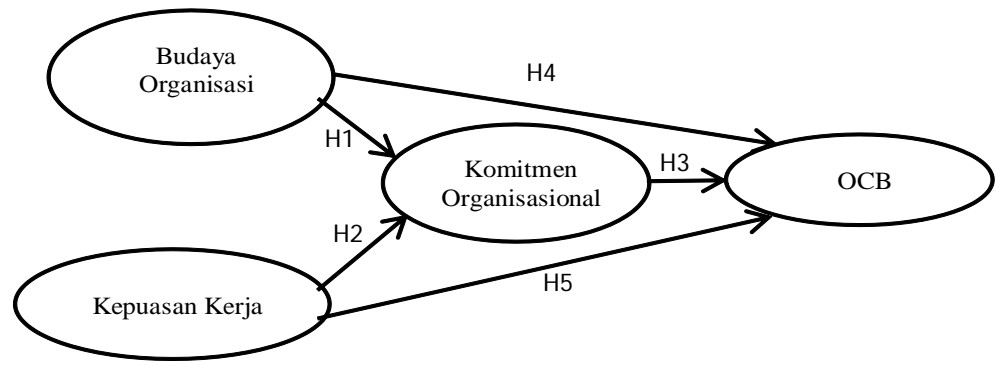

Gambar 1. Model Konseptual Penelitian 
Nongo and Ikyanyon (2012) dalam studinya pada karyawan usaha kecil dan menengah di Makurdi, menyatakan bahwa involvement dan adaptibility berhubungan signifikan dengan komitmen organisasional, sedangkan consistency dan mission tidak berhubungan dengan komitmen organisasional. Menurut Antonio and Miguel (2013), adanya penyesuaian yang lebih baik antara persepsi budaya organisasi dan nilai-nilai yang telah dianut organisasi memiliki hubungan yang positip terhadap komitmen organisasional. Rahmani et al. (2015) melakukan studi mengenai hubungan antara budaya organisasional dan komitmen organisasional pada karyawan beberapa rumah sakit yang berada di wilayah Teheran, menyatakan bahwa terdapat hubungan yang signifikan antara budaya organisasional dan komitmen organisasional.

H1: Budaya organisasional berpengaruh positif terhadap komitmen organisasional perawat.

Zeinabadi (2010) mengukur kepuasan kerja dari dua pengukuran yaitu pengukuran kepuasan kerja intrinsik dan ekstrinsik, diperoleh kesimpulan bahwa secara umum kepuasan kerja berpengaruh positif terhadap komitmen organisasi, terutama pada dimensi komitmen nilai. Azeem (2010) menyatakan bahwa kepuasan kerja dan beberapa aspek yang terdapat di dalamnya secara signifikan menjadi prediktor komitmen organisasi. Yücel (2012) menyatakan bahwa kepuasan kerja merupakan satu faktor yang penting terhadap komitmen organisasional. Penelitian Anari (2012) pada para guru di Kerman menyimpulkan adanya hubungan positif yang signifikan antara kepuasan kerja dan komitmen organisasional.

H2: Kepuasan kerja berpengaruh positif terhadap komitmen organisasional perawat.

Salehi and Gholtash (2011) dalam studi yang dilakukan pada bidang akademisi, diperoleh hasil bahwa komitmen organisasional berpengaruh positif terhadap OCB, yang diartikan, semakin tinggi komitmen anggota fakultas terhadap oranisasinya, makin semakin tinggi pula OCB mereka. Sementara, penelitian Davoudi (2012) pada karyawan asuransi di Iran, menunjukkan bahwa affective commitment dan normative commitment memberikan implikasi positif terhadap OCB, sedangkan continuance commitment tidak signifikan berpengaruh terhadap OCB. Namun, Sjahruddin dan Sudiro (2013); Rehan dan Islam (2013); serta Suparjo dkk (2013), samasama menyatakan bahwa terdapat hubungan yang positif dan langsung antara komitmen organisasional dan OCB. Dengan demikian, maka dapat diajukan hipotesis sebagai berikut:

H3: Komitmen organisasional berpengaruh positif terhadap OCB perawat.

Penelitian Mohant and Rath (2012) pada tiga bidang organisasi, yaitu organisasi manufaktur, perbankan dan teknologi informasi, menunjukkan adanya hubungan yang signifikan antara budaya organisasional dan OCB pada ketiga jenis organisasi tersebut. Menurut Harwiki (2013), budaya organisasional dan komitmen organisasional berpengaruh positif dan signifikan terhadap OCB. Khan dan Rashid (2012) menyatakan bahwa variabel budaya organisasi tidak secara signifikan menjelaskan OCB, namun akan signifikan dengan adanya mediasi komitmen organisasional. Darsana (2013) menyatakan bahwa terdapat hubungan yang positif dan signifikan antara budaya organisasional dan OCB. Rahmani et al. (2015) melakukan studi mengenai hubungan antara budaya organisasional dan komitmen organisasional pada karyawan beberapa rumah sakit yang berada di wilayah Teheran, menyatakan bahwa terdapat hubungan yang signifikan antara budaya organisasional dan komitmen organisasional.

H4a: Budaya organisasional berpengaruh positif terhadap OCB perawat.

H4b: Budaya organisasional berpengaruh positif dan tidak langsung terhadap $O C B$ perawat melalui komitmen organisasional.

Penelitian pada perawat di rumah sakit Taiwan menunjukkan bahwa rumah sakit dapat meningkatkan OCB karyawan dengan mempengaruhi organization's ethical climate, kepuasan kerja, dan komitmen organisasional (Huang et al., 2012). PavalacheIlie (2014) menyatakan bahwa orang yang merasa puas dengan pekerjaannya akan cenderung untuk sering mengadopsi OCB. Penelitian Arif dan Chohan (2012), yang dilakukan pada karyawan bank di Pakistan menunjukkan hasil bahwa kepuasan kerja dengan segala aspek pendukungnya, yang dikembangkan dari Teori Dua Faktor Herzberg berhubungan signifikan dan sangat menjelaskan OCB karyawan. Berdasarkan kajian empiris ini, maka dapat dirumuskan hipotesis sebagai berikut:

H5a: Kepuasan kerja berpengaruh positif terhadap OCB perawat.

H5b: Kepuasan kerja berpengaruh positif dan tidak langsung terhadap OCB perawat melalui komitmen organisasional. 


\section{METODE PENELITIAN}

Penelitian dilakukan pada rumah sakit umum swasta yang ada di kota Denpasar untuk mengeksplorasi variabel-variabel yang mempengaruhi OCB karyawan pada industri rumah sakit. Rumah sakit umum swasta dipilih sebagai lokasi penelitian mengingat fungsi dan keberadaan rumah sakit umum yang sangat penting dalam memberikan pelayanan jasa kesehatan serta pengobatan, baik yang bersifat pencegahan maupun tindakan perawatan. Berdasarkan Peraturan Menteri Kesehatan Republik Indonesia Nomor 56 Tahun 2014 tentang Klasifikasi dan Perijinan Rumah Sakit, rumah sakit umum diklasifikasikan berdasarkan pelayanan, sumber daya manusia, peralatan dan sarana dan prasarana yang tersedia di rumah sakit umum tersebut, serta data Dinas Kesehatan Kota Denpasar menyatakan bahwa rumah sakit umum swasta yang ada di Kota Denpasar saat ini memiliki klasifikasi tipe C dan D. Belum ada rumah sakit umum swasta di Kota Denpasar yang memiliki klasifikasi tipe A atau B. Penulis melakukan studi pada lima rumah sakit umum swasta tipe C di Kota Denpasar yang memiliki fasilitas pelayanan, peralatan, sarana dan prasarana serta sumber daya manusia yang lebih banyak dan kompleks dibandingkan yang tipe D. Kemampuan serta perilaku keorganisasian para tenaga medis terutama para perawat akan menjadi penilaian kualitas pelayanan yang diberikan rumah sakit tersebut.

Desain penelitian adalah penelitian kausalitas, dilakukan di rumah sakit umum swasta tipe $\mathrm{C}$ di Kota Denpasar dengan subyek penelitian para perawat rumah sakit umum swasta tipe $\mathrm{C}$ yang ada di Kota Denpasar. Obyek penelitian adalah kepuasan kerja, budaya organisasional, komitmen organisasional dan organizational citizenship behavior (OCB). Jumlah responden penelitian adalah 85 orang perawat rumah sakit umum swasta tipe $\mathrm{C}$ yang ada di Kota Denpasar yang diambil dengan teknik pengambilan sampel teknik sampling acak proporsional.

Variabel bebas adalah budaya organisasional (X1) dan kepuasan kerja (X2). Variabel terikat adalah komitmen organisasional (Y1) dan organizational citizenship behavior-OCB (Y2). Budaya organisasional (X1) merupakan norma-norma dan nilai-nilai yang mengarahkan perilaku anggota organisasi, sehingga setiap anggota akan berperilaku sesuai dengan budaya yang berlaku, agar diterima oleh lingkungannya. Kepuasan kerja (X2) merupakan sikap karyawan terhadap situasi dan kondisi kerja yang timbul karena adanya interaksi yang terjadi terhadap pekerjaan mereka dengan pikiran, perasaan, dan emosi mereka. Komitmen organisasional (Y1) merupakan sikap yang menunjukkan loyalitas karyawan terhadap organisasi dan merupakan proses berkelanjutan bagaimana seorang anggota organisasi mengekspresikan perhatian mereka kepada kesuksesan dan kebaikan organisasinya. OCB (Y2) merupakan perilaku individu yang bersifat bebas (discretionary), yang tidak secara langsung atau eksplisit mendapat penghargaan dari sistem imbalan formal, dan yang secara keseluruhan mendorong keefektifan fungsifungsi organisasi, yang diwujudkan dalam berbagai bentuk seperti kesetiaan, kepatuhan organisasi, relawan dan kesediaan membantu orang lain.

Pengujian hipotesis untuk menghasilkan model yang layak (fit) mengunakan Structural Equation Model (SEM) dengan pendekatan variance based dengan Partial Least Square (PLS) (Sholihin dan Ratmono, 2013).

\section{HASIL PENELITIAN DAN PEMBAHASAN}

Lima rumah sakit umum swasta tipe $C$ di Kota Denpasar yang menjadi obyek penelitian, telah bersedia memberikan data yang diperlukan dalam penelitian. Karakteristik responden penelitian dapat dilihat pada Tabel 1 .

Tabel 1 menunjukkan sebagian besar responden dalam penelitian ini berusia antara $26 \mathrm{~s} / \mathrm{d}$ 30 tahun sebanyak 43 orang (50,59 persen). Jenis kelamin terbesar responden adalah perempuan sebanyak 77 orang (90,59 persen), yang mengindikasikan bahwa perawat perempuan lebih diminati oleh organisasi rumah sakit karena perempuan dinilai memiliki kesabaran yang lebih tinggi dalam memberikan pelayanan kepada pasien maupun masyarakat yang membutuhkan. Tingkat pendidikan responden didominasi tingkat pendidikan D3 Keperawatan sebanyak 54 orang (63,53 persen). Hal ini menunjukkan bahwa perawat yang memiliki jenjang pendidikan D3 Keperawatan dianggap lebih siap untuk melaksanakan pekerjaan keperawatan. Masa kerja para perawat sebagian besar antara 4 s/d 6 tahun sebanyak 28 orang (32,94 persen). Hal ini menunjukkan bahwa sebagian besar perawat memiliki pengalaman kerja yang dapat dikatakan cukup dalam memberikan pelayanan kepada masyarakat terutama pasien.

\section{Budaya Organisasional}

Variabel budaya organisasional diukur melalui persepsi responden terhadap empat indikator budaya organisasional yaitu keterlibatan (involvement), 
Tabel 1. Karakteristik Responden

\begin{tabular}{cccc}
\hline & Kategori & Jumlah (orang) & Prosentase (\%) \\
\hline Usia & 21 s/d 25 tahun & 20 & 23,53 \\
& 26 s/d 30 tahun & 43 & 50,59 \\
& 31 s/d 35 tahun & 9 & 10,59 \\
& 36 s/d 40 tahun & 11 & 12,94 \\
& $\geq 41$ tahun & 2 & 2,35 \\
\hline & Total & 85 & 100,00 \\
\hline Jenis Kelamin & Laki-laki & 8 & 9,41 \\
& Perempuan & 77 & 90,59 \\
\hline & Total & 85 & 100,00 \\
\hline Pendidikan & D3 Keperawatan & 54 & 63,53 \\
& D3 Kebidanan & 16 & 18,82 \\
& S1 Keperawatan & 15 & 17,65 \\
\hline & Total & 85 & 100,00 \\
\hline Masa Kerja & 1 s/d 3 tahun & 27 & 31,76 \\
& 4 s/d 6 tahun & 28 & 32,94 \\
& 7 s/d 9 tahun & 21 & 24,71 \\
& $\geq 10$ tahun & 9 & 10,59 \\
\hline & Total & 85 & 100,00 \\
\hline
\end{tabular}

Sumber: Hasil Pengolahan Data Penelitian

konsistensi (consistency), kemampuan beradaptasi (adaptability) dan misi (mission).

Tabel 2 menunjukkan bahwa nilai rata-rata yang dihasilkan dari masing-masing indikator adalah cukup tinggi. Ini mengindikasikan persepsi responden terhadap budaya organisasional berada pada kategori baik. Perilaku pemberian peringatan apabila melanggar aturan perusahaan memiliki nilai rata-rata tertinggi $(4,13)$, artinya, perilaku tersebut paling dominan dalam merefleksikan konstruk budaya organisasional.

Tabel 2. Deskripsi Variabel Budaya Organisasional

\begin{tabular}{|c|c|c|c|}
\hline No & Indikator Budaya Organisasional & Rata-Rata & Kriteria \\
\hline \multirow[t]{3}{*}{1} & Involvement (keterlibatan) & 3,85 & Baik \\
\hline & $\begin{array}{l}\text { Pemberian kesempatan kepada karyawan untuk terlibat dalam proses } \\
\text { perencanaan organisasi sampai pada batas tertentu }\end{array}$ & 3,81 & Baik \\
\hline & $\begin{array}{l}\text { Pemberian kesempatan kepada karyawan untuk ikut aktif dalam setiap kegiatan } \\
\text { yang diselenggarakan organisasi }\end{array}$ & 3,88 & Baik \\
\hline \multirow[t]{2}{*}{2} & Consistency (konsistensi) & 4,13 & Baik \\
\hline & Pemberian peringatan apabila melanggar aturan perusahaan & 4,13 & Baik \\
\hline \multirow[t]{4}{*}{3} & Adaptability (kemampuan beradaptasi) & 4,02 & Baik \\
\hline & $\begin{array}{l}\text { Kemampuan perusahaan memahami kondisi persaingan usaha yang dihadapi } \\
\text { perusahaan }\end{array}$ & 3,94 & Baik \\
\hline & Kemampuan perusahaan beradaptasi terhadap perkembangan lingkungan sekitar & 4,01 & Baik \\
\hline & Kebijakan perusahaan selalu berorientasi pada kepentingan pasien & 4,12 & Baik \\
\hline \multirow[t]{4}{*}{4} & Mission (misi) & 4,01 & Baik \\
\hline & Kejelasan arah serta tujuan jangka panjang perusahaan & 4,12 & Baik \\
\hline & Kejelasan sasaran-sasaran yang ditetapkan perusahaan & 3,94 & Baik \\
\hline & Kejelasan prosedur kerja yang ditetapkan perusahaan & 3,98 & Baik \\
\hline
\end{tabular}

Sumber: Data primer, diolah.

\section{Kepuasan Kerja}

Variabel kepuasan kerja diukur melalui persepsi responden terhadap empat indikator kepuasan kerja yaitu kesempatan untuk berkembang, pekerjaan, pengawasan (supervision), gaji (salary) dan rekan kerja (co-worker).

Tabel 3 menunjukkan bahwa persepsi responden terhadap kepuasan kerja dapat dikatakan berada pada kategori baik. Nilai rata-rata yang dihasilkan dari masing-masing indikator adalah cukup tinggi, kecuali untuk indikator gaji. Indikator rekan kerja memberikan nilai rata-rata yang tertinggi
$(4,26)$, yang menggambarkan kepuasan perawat terhadap hubungan dengan sesama perawat maupun karyawan yang lain dalam perusahaan telah terjalin dengan baik dan perilaku tersebut paling dominan dalam membentuk konstruk kepuasan kerja.

\section{Komitmen Organisasional}

Variabel komitmen organisasional diukur melalui persepsi responden terhadap tiga indikator komitmen organisasional yaitu affective commitment, continuance commitment dan normative commitment. 
Tabel 3. Deskripsi Variabel Kepuasan Kerja

\begin{tabular}{clcc}
\hline No & \multicolumn{1}{c}{ Indikator /Item Kepuasan Kerja } & Rata-Rata & Kriteria \\
\hline 1 & Kesempatan Untuk Berkembang & 3,93 & Baik \\
& Kesempatan promosi yang diberikan organisasi & 3,92 & Baik \\
& Kesempatan pengembangan diri dalam organisasi & 3,98 & Baik \\
& Kepuasan dengan konsep kenaikan pangkat & 3,88 & Baik \\
\hline 2 & Pekerjaan & 4,20 & Baik \\
& Kepuasan dengan pekerjaan & 4,15 & Baik \\
& Pekerjaan memberikan kesempatan untuk terus belajar & 4,24 & Baik \\
& Kesempatan menerima tanggung jawab atas pekerjaan & 4,20 & Baik \\
\hline 3 & Pengawasan (supervision) & 4,08 & Baik \\
& Kemampuan atasan mendelegasikan tanggung jawab & 4,04 & Baik \\
& Kemampuan atasan membimbing bawahan & 4,02 & Baik \\
& Perhatian atasan terhadap bawahan & 4,13 & Baik \\
& Bantuan teknis atasan kepada bawahan & 4,12 & Baik \\
\hline 4 & Gaji (salary) & 3,43 & Baik \\
& Kesesuaian penghasilan dengan beban pekerjaan & 3,40 & Baik \\
& Keadilan penghasilan yang diterima dengan karyawan lain dengan beban kerja & 3,46 & Baik \\
& yang sama & & \\
\hline 5 & Rekan Kerja (co-worker) & 4,26 & Baik \\
& Kepuasan hubungan kerja yang terjalin dengan rekan kerja & 4,31 & Baik \\
Kepuasan terhadap dukungan rekan kerja dalam organisasi & 4,22 & Baik \\
\hline
\end{tabular}

Sumber: Hasil Pengolahan Data Penelitian

Tabel 4 menunjukkan bahwa persepsi responden terhadap komitmen organisasional berada pada kategori baik. Nilai rata-rata yang dihasilkan dari indikator affective commitment dan normative commitment adalah lebih tinggi bila dibandingkan dengan indikator continuance commitment. Hasil ini memperlihatkan bahwa komitmen organisasional di industri rumah sakit ini lebih banyak dipengaruhi oleh hal-hal yang bersifat emosional (affective commitment dan normative commitment) dibandingkan dengan pertimbangan untung rugi yang bersifat transaksional (continuance commitment). Organizational Citizenship Behavior (OCB)

Variabel organizational citizenship behavior diukur melalui persepsi responden terhadap lima indikator organizational citizenship behavior yaitu altruism, civic virtue, concientiousness, courtesy dan sportmanship.

\section{Tabel 4. Deskripsi Variabel Komitmen Organisasional}

\begin{tabular}{clcc}
\hline No & \multicolumn{1}{c}{ Indikator/Item Komitmen Organisasional } & Rata-Rata & Kriteria \\
\hline 1 & Affective Commitment & 3,95 & Baik \\
& Keterikatan emosional yang tinggi pada organisasi & 3,69 & Baik \\
& Kebanggaan menjadi bagian dari organisasi & 4,08 & Baik \\
Keinginan yang kuat untuk terus bekerja pada organisasi & 4,07 & Baik \\
\cline { 2 - 4 } 2 & Continuance Commitment & 3,64 & Baik \\
Tindakan meninggalkan organisasi akan sangat beresiko bagi karyawan & 3,69 & Baik \\
Tanggungan kerugian yang besar apabila harus meninggalkan organisasi & 3,59 & Baik \\
3 Normative Commitment & 4,02 & Baik \\
Kewajiban untuk tetap bertahan dalam organisasi & 4,06 & Baik \\
Tanggung jawab yang besar untuk tetap bertahan di perusahaan & 4,06 & Baik \\
Perasaan tidak etis bila pindah ke organisasi lain & 3,95 & Baik \\
\hline
\end{tabular}

Sumber: Hasil Pengolahan Data Penelitian

Tabel 5 menunjukkan nilai rata-rata yang dihasilkan dari masing-masing indikator adalah cukup tinggi. Persepsi perawat terhadap indikator-indikator OCB adalah tinggi, artinya para perawat rumah sakit umum swasta tipe $\mathrm{C}$ yang ada di Kota Denpasar sudah mampu menerapkan nilai-nilai peran kerja ekstra yang baik. Hasil rata-rata tertinggi ditunjukkan pada indikator courtesy $(4,72)$, yang berarti para perawat memiliki persepsi perilaku yang sangat baik dalam menjaga hubungan dengan rekan kerja dan menghindari permasalahan maupun perselisihan dengan rekan kerja.

\section{Hasil Evaluasi Model Pengukuran (Outer Model)}

Penelitian ini menggunakan model persamaan struktural dengan pendekatan Partial Least Square (PLS ) sebagai metode analisis. Penggunaan PLS sebagai metode analisis membutuhkan beberapa tahap pemodelan persamaan struktural. Evaluasi 
Tabel 5. Deskripsi Variabel Organizational Citizenship Behavior (OCB)

\begin{tabular}{|c|c|c|c|}
\hline No & Indikator/Item OCB & Rata-Rata & Kriteria \\
\hline \multirow[t]{4}{*}{1} & Altruism & 4,19 & Baik \\
\hline & Kesediaan menggantikan pekerjaan rekan kerja yang berhalangan hadir & 3,98 & Baik \\
\hline & Inisiatif membantu rekan kerja yang beban kerjanya berlebih & 4,31 & Sangat Baik \\
\hline & $\begin{array}{l}\text { Kesediaan membantu rekan kerja yang memiliki masalah dengan } \\
\text { pekerjaan }\end{array}$ & 4,28 & Baik \\
\hline \multirow[t]{4}{*}{2} & Civic virtue & 4,24 & Baik \\
\hline & Tanggung jawab dalam melakukan setiap pekerjaan & 4,61 & Sangat Baik \\
\hline & Kepedulian terhadap perubahan yang terjadi dalam organisasi & 4,13 & Baik \\
\hline & Partisipasi dalam berbagai kegiatan yang diselenggarakan oleh organisasi & 3,99 & Baik \\
\hline \multirow[t]{4}{*}{3} & Concientiousness & 4,18 & Baik \\
\hline & Kesediaan melakukan pekerjaan dengan sepenuh hati & 4,58 & Sangat Baik \\
\hline & Usaha untuk menyelesaikan pekerjaan sebelum waktunya & 4,29 & Baik \\
\hline & $\begin{array}{l}\text { Usaha untuk melakukan pekerjaan melebihi dari apa yang seharusnya } \\
\text { dilakukan }\end{array}$ & 3,66 & Baik \\
\hline \multirow[t]{4}{*}{4} & Courtesy & 4,72 & Sangat Baik \\
\hline & Usaha untuk menjaga hubungan baik dengan rekan kerja & 4,73 & Sangat Baik \\
\hline & Usaha untuk tidak membuat masalah dengan rekan kerja & 4,68 & Sangat Baik \\
\hline & Usaha untuk menghindari terjadinya perselisihan dengan rekan kerja & 4,74 & Sangat Baik \\
\hline \multirow[t]{4}{*}{5} & Sportmanship & 3,86 & Baik \\
\hline & Kemauan menerima setiap kebijakan yang ditetapkan oleh organisasi & 4,06 & Baik \\
\hline & Kemauan menerima ketidaknyamanan yang terjadi di tempat kerja & 3,51 & Baik \\
\hline & Tidak membesar-besarkan permasalahan yang terjadi dalam organisasi & 4,02 & Baik \\
\hline
\end{tabular}

Sumber: Hasil pengolahan data penelitian

model pengukuran berdasarkan outer loading untuk indikator reflektif dengan kriteria, yaitu indikator reflektif dianggap valid jika memiliki nilai loading di atas 0,5 dan atau nilai statistik-t di atas 1,96. Ini berarti model memenuhi convergent validity. Indikator formatif dievaluasi dengan outer weight, yaitu dengan melihat ukuran dan signifikansi dari nilai weight-nya.

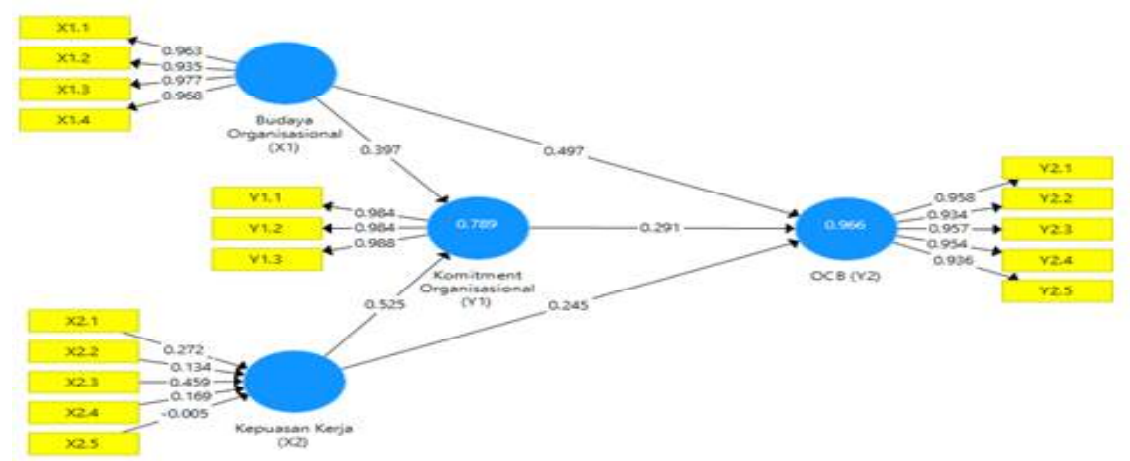

\section{Gambar 2. Evaluasi Model Persamaan Struktural}

Tabel 6 menunjukkan bahwa semua indikator reflektif dari budaya organisasi, komitmen organisasi dan OCB penelitian ini telah memenuhi convergent validity karena tidak ada nilai loading di bawah 0,5 dan nilai statistik- $\mathrm{T}>1,96$.

Nilai outer weight untuk indikator formatif pada variabel kepuasan kerja ditunjukkan pada Tabel 7 dimana nilai weight dari indikator formatif kepuasan kerja tidak semua signifikan membentuk variabel laten kepuasan kerja karena terdapat indikator yang nilai statistik- $\mathrm{T}<1,96$. Hasil regresi ini mengindikasikan bahwa variabel kepuasan kerja secara statistik tidak dapat diuji lebih lanjut dalam model struktural. Menghapus atau menghilangkan indikator formatif dalam suatu model penelitian, menyebabkan model penelitian kehilangan makna dan kehilangan dasar tujuan pengujian. Sholihin dan Ratmono (2013) telah menjelaskan bahwa walaupun indikator formatif tidak signifikan tetapi tetap dapat dipertahankan atau tidak dihapus dalam model apabila memiliki outer loading $>0,5$. Hair et al. (2013) berargumen bahwa peneliti harus berhati-hati untuk menghapus indikator formatif karena dihapusnya salah satu indikator formatif dapat mengubah isi secara keseluruhan. Peneliti sebaiknya tidak serta merta menghapus indikator formatif, meskipun indicator weight tidak signifikan. Semua indikator formatif dari variabel kepuasan kerja tetap dipertahankan dalam model karena nilai outer loading pada indikator variabel kepuasan kerja memiliki nilai outer loading $>0,5$. 
Tabel 6. Hasil Pengujian Convergent Validity

\begin{tabular}{lccccc}
\hline & $\begin{array}{c}\text { Original } \\
\text { Sample }(\mathrm{O})\end{array}$ & $\begin{array}{c}\text { Sample } \\
\text { Mean }(\mathrm{M})\end{array}$ & $\begin{array}{c}\text { Standard } \\
\text { Error } \\
(\text { STERR })\end{array}$ & $\begin{array}{c}\text { T Statistics } \\
(\mid \text { OOSTERR })\end{array}$ & $\begin{array}{c}\text { P } \\
\text { Values }\end{array}$ \\
\hline X1.1 <- Budaya Organisasional & $\mathbf{0 , 9 6 3}$ & 0,963 & 0,008 & $\mathbf{1 2 4 , 2 5 3}$ & $\mathbf{0 , 0 0 0}$ \\
X1.2 <- Budaya Organisasional & $\mathbf{0 , 9 3 5}$ & 0,935 & 0,019 & $\mathbf{4 9 , 6 3 2}$ & $\mathbf{0 , 0 0 0}$ \\
X1.3 <- Budaya Organisasional & $\mathbf{0 , 9 7 7}$ & 0,977 & 0,005 & $\mathbf{1 8 1 , 7 3 4}$ & $\mathbf{0 , 0 0 0}$ \\
X1.4 <- Budaya Organisasional & $\mathbf{0 , 9 6 8}$ & 0,969 & 0,006 & $\mathbf{1 5 5 , 7 7 3}$ & $\mathbf{0 , 0 0 0}$ \\
x2.1 -> Kepuasan Kerja & $\mathbf{0 , 9 7 0}$ & 0,967 & 0,011 & $\mathbf{8 5 , 3 5 9}$ & $\mathbf{0 , 0 0 0}$ \\
x2.2 -> Kepuasan Kerja & $\mathbf{0 , 9 5 0}$ & 0,943 & 0,020 & $\mathbf{4 8 , 3 9 7}$ & $\mathbf{0 , 0 0 0}$ \\
x2.3 -> Kepuasan Kerja & $\mathbf{0 , 9 8 3}$ & 0,978 & 0,008 & $\mathbf{1 2 1 , 9 9 6}$ & $\mathbf{0 , 0 0 0}$ \\
X2.4 -> Kepuasan Kerja & $\mathbf{0 , 9 6 0}$ & 0,954 & 0,018 & $\mathbf{5 4 , 5 2 1}$ & $\mathbf{0 , 0 0 0}$ \\
x2.5 -> Kepuasan Kerja & $\mathbf{0 , 9 2 4}$ & 0,917 & 0,030 & $\mathbf{3 1 , 0 9 9}$ & $\mathbf{0 , 0 0 0}$ \\
Y1.1 <- Komitmen Organisasional & $\mathbf{0 , 9 8 4}$ & 0,983 & 0,005 & $\mathbf{2 1 3 , 1 7 6}$ & $\mathbf{0 , 0 0 0}$ \\
Y1.2 <- Komitmen Organisasional & $\mathbf{0 , 9 8 4}$ & 0,984 & 0,004 & $\mathbf{2 5 4 , 9 4 3}$ & $\mathbf{0 , 0 0 0}$ \\
Y1.3 <- Komitmen Organisasional & $\mathbf{0 , 9 8 8}$ & 0,987 & 0,003 & $\mathbf{2 9 3 , 9 1 1}$ & $\mathbf{0 , 0 0 0}$ \\
Y2.1 <- OCB & $\mathbf{0 , 9 5 8}$ & 0,958 & 0,008 & $\mathbf{1 2 5 , 7 3 6}$ & $\mathbf{0 , 0 0 0}$ \\
Y2.2 <- OCB & $\mathbf{0 , 9 3 4}$ & 0,931 & 0,013 & $\mathbf{7 1 , 5 2 2}$ & $\mathbf{0 , 0 0 0}$ \\
Y2.3 <- OCB & $\mathbf{0 , 9 5 7}$ & 0,956 & 0,008 & $\mathbf{1 1 4 , 4 5 3}$ & $\mathbf{0 , 0 0 0}$ \\
Y2.4 <- OCB & $\mathbf{0 , 9 5 4}$ & 0,954 & 0,008 & $\mathbf{1 2 6 , 0 2 5}$ & $\mathbf{0 , 0 0 0}$ \\
Y2.5 <- OCB & $\mathbf{0 , 9 3 6}$ & 0,935 & 0,012 & $\mathbf{7 5 , 4 0 7}$ & $\mathbf{0 , 0 0 0}$ \\
\hline Sumber & & & &
\end{tabular}

Sumber: Hasil pengolahan data penelitian

Tabel 7. Outer Weight Variabel Penelitian

\begin{tabular}{lccccc}
\hline & $\begin{array}{c}\text { Original Sample } \\
(\mathrm{O})\end{array}$ & $\begin{array}{c}\text { Sample Mean } \\
(\mathrm{M})\end{array}$ & $\begin{array}{c}\text { Standard Error } \\
(\text { STERR })\end{array}$ & $\begin{array}{c}\text { T Statistics } \\
(\mid \mathrm{O} / \text { STERR })\end{array}$ & P Values \\
\hline x2.1 -> Kepuasan Kerja & $\mathbf{0 , 2 7 2}$ & 0,311 & 0,148 & $\mathbf{1 , 8 4 5}$ & $\mathbf{0 , 0 6 6}$ \\
x2.2 -> Kepuasan Kerja & $\mathbf{0 , 1 3 4}$ & 0,103 & 0,173 & $\mathbf{0 , 7 7 5}$ & $\mathbf{0 , 4 3 9}$ \\
x2.3 -> Kepuasan Kerja & $\mathbf{0 , 4 5 9}$ & 0,439 & 0,154 & $\mathbf{2 , 9 8 0}$ & $\mathbf{0 , 0 0 3}$ \\
x2.4 -> Kepuasan Kerja & $\mathbf{0 , 1 6 9}$ & 0,172 & 0,183 & $\mathbf{0 , 9 2 4}$ & $\mathbf{0 , 3 5 6}$ \\
x2.5 -> Kepuasan Kerja & $\mathbf{- 0 , 0 0 5}$ & $-0,001$ & 0,155 & $\mathbf{0 , 0 3 4}$ & $\mathbf{0 , 9 7 3}$ \\
\hline
\end{tabular}

Sumber: Hasil pengolahan data penelitian

Tabel 8 memperlihatkan bahwa cross loadings yang diperoleh variabel laten untuk memprediksi indikatornya sendiri lebih besar daripada indikator

variabel laten yang lainnya. Interpretasi yang dapat diberikan dari hasil cross loadings ini bahwa variabel laten telah memenuhi discriminant validity.

Tabel 8. Hasil Pengujian Diskriminant Validity Berdasarkan Cross Loadings

\begin{tabular}{ccccc}
\hline Item & Budaya Organisasi & Kepuasan Kerja & Komitmen Organisasi & OCB \\
\hline X1.1 & $\mathbf{0 , 9 6 3}$ & 0,841 & 0,825 & 0,915 \\
X1.2 & $\mathbf{0 , 9 3 5}$ & 0,773 & 0,781 & 0,857 \\
X1.3 & $\mathbf{0 , 9 7 7}$ & 0,840 & 0,830 & 0,937 \\
X1.4 & $\mathbf{0 , 9 6 8}$ & 0,833 & 0,814 & 0,947 \\
X2.1 & 0,826 & $\mathbf{0 , 9 7 0}$ & 0,832 & 0,900 \\
X2.2 & 0,838 & $\mathbf{0 , 9 5 0}$ & 0,816 & 0,880 \\
X2.3 & 0,833 & $\mathbf{0 , 9 8 3}$ & 0,853 & 0,901 \\
X2.4 & 0,831 & $\mathbf{0 , 9 6 0}$ & 0,834 & 0,880 \\
X2.5 & 0,809 & $\mathbf{0 , 9 2 4}$ & 0,801 & 0,848 \\
Y1.1 & 0,857 & $\mathbf{0 , 9 8 4}$ & 0,917 \\
Y1.2 & 0,840 & 0,844 & $\mathbf{0 , 9 8 4}$ & 0,906 \\
Y1.3 & 0,837 & 0,852 & $\mathbf{0 , 9 8 8}$ & 0,903 \\
Y2.1 & 0,822 & 0,886 & 0,896 & $\mathbf{0 , 9 5 8}$ \\
Y2.2 & 0,881 & 0,910 & 0,826 & $\mathbf{0 , 9 3 4}$ \\
Y2.3 & 0,919 & 0,855 & 0,888 & $\mathbf{0 , 9 5 7}$ \\
Y2.4 & 0,952 & 0,875 & 0,838 & $\mathbf{0 , 9 5 4}$ \\
Y2.5 & 0,911 & 0,838 & 0,923 & $\mathbf{0 , 9 3 6}$ \\
\hline
\end{tabular}

Sumber: Hasil pengolahan data penelitian 
Tabel 9 menunjukkan bahwa nilai AVE untuk variabel budaya organisasional, komitmen organisasional dan OCB memiliki nilai AVE di atas
0,50 , yang mengindikasikan bahwa model telah mempunyai discriminant validity yang baik.

\begin{tabular}{|c|c|}
\hline Variabel & AVE \\
\hline Budaya Organisasi & 0,924 \\
\hline Kepuasan Kerja & - \\
\hline Komitmen Organisasi & 0,971 \\
\hline $\mathrm{OCB}$ & 0,898 \\
\hline
\end{tabular}

Sumber: Hasil pengolahan data penelitian

Evaluasi model pengukuran berdasarkan composite reliability berguna untuk melihat reliabilitas konstruk. Suatu konstruk dikatakan reliabel jika nilai composite reliability di atas 0,70 . Tabel 10 menunjukkan nilai composite reliability.

Tabel 10. Hasil Pengujian Composite Reliability

\begin{tabular}{lcc}
\hline Variabel & Composite Reliability & Keterangan \\
\hline Budaya Organisasional & 0,980 & Reliabel \\
Kepuasan Kerja & - & - \\
Komitmen Organisasional & 0,990 & Reliabel \\
OCB & 0,978 & Reliabel \\
\hline
\end{tabular}

Sumber: Hasil pengolahan data penelitian

Tabel 10 menunjukkan bahwa composite reliability mempunyai nilai di atas 0,70 . Nilai ini mengindikasikan bahwa hasil composite reliability adalah baik atau variabel laten penelitian telah reliabel.

\section{Goodness Of Fit - Model Struktural (Inner Model)}

Tabel 11. $R$-square $\left(\mathbf{R}^{2}\right)$ Variabel Laten Endogen

\begin{tabular}{lc}
\hline Variabel & $\mathbf{R}^{2}$ \\
\hline Komitmen Organisasi & 0,789 \\
OCB & 0,966 \\
\hline
\end{tabular}

Sumber: Hasil pengolahan data penelitian

Berdasarkan Tabel 11 dapat dihitung nilai predictive-relevance $\left(\mathrm{Q}^{2}\right)$, yaitu: 1 - $\left(1\right.$ - $\left.0,789^{2}\right)(1$ $\left.-0,966^{2}\right)=0,975$. Hasil perhitungan ini menunjukkan bahwa nilai $\mathrm{Q}^{2}$ lebih besar dari $0(0,975>0)$, sehingga dapat diinterpretasikan bahwa model baik karena memiliki nilai prediktif yang relevan, yaitu 97,5 persen variasi pada variabel OCB mampu dijelaskan oleh variabel-variabel yang digunakan yaitu variabel budaya organisasional, variabel kepuasan kerja dan variabel komitmen organisasional, sedangkan sisanya 2,5 persen dijelaskan oleh variabel lain yang belum masuk ke dalam model. Budaya organisasional memberikan pengaruh yang paling besar terhadap OCB, yaitu 0,497, selanjutnya komitmen organisasional $(0,291)$ dan kepuasan kerja $(0,245)$.

\section{Pengujian Hipotesis}

Pengujian hipotesis dilakukan dengan menggunakan uji-T (T-test) pada tiap-tiap jalur pengaruh antara variabel bebas dan variabel terikat.
Hasil perhitungan jalur (path) secara keseluruhan dapat dilihat pada koefisien jalur dan pengaruh total pada Tabel 12.

\section{Pengujian Hipotesis 1}

Nilai koefisien jalurantara variabel budaya organisasional dengan variabel komitmen organisasional adalah sebesar 0,397 dengan Tstatistik sebesar 5,382 atau $\mathrm{T}>1,96$ dan $\mathrm{p}$ value $=0,000$.

Hasil ini mengindikasikan bahwa variabel budaya organisasional berpengaruh langsung secara positif dan signifikan terhadap variabel komitmen organisasional pada perawat di rumah sakit umum swasta tipe $\mathrm{C}$ yang ada di Kota Denpasar. Hipotesis 1 yang menyatakan bahwa budaya organisasional berpengaruh positif terhadap komitmen organisasional diterima.

\section{Pengujian Hipotesis 2}

Nilai koefisien jalurantara variabel kepuasan kerja dengan variabel komitmen organisasional 
Tabel 12. Hasil Pengujian Hipotesis Dengan PLS

\begin{tabular}{|c|c|c|c|c|}
\hline \multirow{3}{*}{ Variabel } & \multicolumn{4}{|c|}{ Pengaruh Langsung } \\
\hline & \multicolumn{2}{|c|}{ Komitmen Organisasi } & \multicolumn{2}{|c|}{ OCB } \\
\hline & Koefisien & T-stat & Koefisien & T-stat \\
\hline Budaya Organisasional & 0,397 & 5,382 & 0,497 & 15,197 \\
\hline Kepuasan kerja & 0,525 & 7,061 & 0,245 & 6,379 \\
\hline Komitmen organisasional & - & - & 0,291 & 7,071 \\
\hline $\begin{array}{l}\text { Budaya Organisasional } \\
\text { Kepuasan Kerja }\end{array}$ & - & $\begin{array}{c}\text { Pengaruh } \\
- \\
-\end{array}$ & $\begin{array}{c}\text { Langsung } \\
0,115 \\
0,152\end{array}$ & $\begin{array}{l}4,703 \\
4,587\end{array}$ \\
\hline & \multicolumn{4}{|c|}{ Pengaruh Total } \\
\hline Budaya Organisasional & - & - & 0,612 & 18,492 \\
\hline Kepuasan kerja & - & - & 0,397 & 11,525 \\
\hline
\end{tabular}

Sumber: Hasil Pengolahan Data Penelitian

adalah sebesar 0,525 dengan T-statistik sebesar 7,061 atau $\mathrm{T}>1,96$ dan $\mathrm{p}$ value=0,000.Ini mengindikasikan bahwa variabel kepuasan kerja berpengaruh langsung secara positif dan signifikan terhadap variabel komitmen organisasional pada perawat di rumah sakit umum swasta tipe $C$ yang ada di Kota Denpasar. Hipotesis 2 yang menyatakan bahwa kepuasan kerja berpengaruh positif terhadap komitmen organisasional diterima.

\section{Pengujian Hipotesis 3a}

Nilai koefisien jalurantara variabel budaya organisasional dengan variabel OCB secara langsung sebelum dimasukkannya variabel komitmen organisasional sebagai mediasi adalah sebesar 0,612 dengan T-statistik sebesar 16,972 atau T>1,96 dan $\mathrm{p}$ value $=0,000$. Ini berarti bahwa variabel budaya organisasional berpengaruh langsung secara positif dan signifikan terhadap variabel OCB pada perawat di rumah sakit umum swasta tipe $C$ yang ada di Kota Denpasar. Hipotesis 3a yang menyatakan bahwa budaya organisasional berpengaruh positif terhadap OCBditerima.

\section{Pengujian Hipotesis 3b}

Penambahan variabel komitmen organisasional sebagai variabel pemediasi memberikan hasil bahwa budaya organisasional berpengaruh positif terhadap komitmen organisasional (koefisien $=0,397 ; p=0,000$ ) dan komitmen organisasional juga berpengaruh positif terhadap OCB (koefisien=0,291; $\mathrm{p}=0,000$ ). Pengaruh langsung budaya organisasional terhadap OCB tetap signifikan (koefisien=0,497; $\mathrm{p}=0,000$ ). Koefisien jalur antara variabel budaya organisasional dengan variabel OCB turun dari 0,612 menjadi 0,497. Pengujian variabel mediasi dengan menggunakan perhitungan nilai Variance Accounted For (VAF) dapat dilihat pada Tabel 13.

\section{Tabel 13. Hasil Pengujian Pemediasi Komitmen Organisasional Pada Pengaruh Budaya Organisasional Terhadap OCB}

\begin{tabular}{llc}
\hline \multicolumn{1}{c}{ Pengaruh } & \multicolumn{1}{c}{ Hubungan Variabel } & Koefisien \\
\hline Pengaruh Langsung & Budaya Organisasional-> OCB (tanpa pemediasi) & 0,612 \\
Pengaruh Tidak Langsung & Budaya Organisasional -> Komitmen Organisasional & 0,397 \\
& Komitmen Organisasional -> OCB & 0,291 \\
& Pengaruh Tidak Langsung = 0,397x0,291 & 0,115 \\
Pengaruh Total & Budaya Organisasional -> OCB $(0,612+0,115)$ & 0,727 \\
VAF & Pengaruh Tidak Langsung/Pengaruh Total $(0,115 / 0,727)$ & 0,158 \\
\hline
\end{tabular}

Sumber: Hasil pengolahan data penelitian

Tabel 13 menunjukkan nilai VAF yang diperoleh pada hubungan tidak langsung variabel budaya organisasional terhadap OCB melalui komitmen organisasional adalah sebesar $0,158(15,8 \%)$. Hasil ini menunjukkan bahwa variabel komitmen organisasional tidak memiliki pengaruh mediasi terhadap hubungan antara budaya organisasional dan OCB. Hipotesis $3 b$ yang menyatakan budaya organisasional berpengaruh tidak langsung terhadap OCB melalui komitmen organisasional, tidak terdukung.

\section{Pengujian Hipotesis 4a}

Nilai koefisien jalurantara variabel kepuasan kerja dengan variabel OCB secara langsung sebelum dimasukkannya variabel komitmen organisasional sebagai mediasi adalah sebesar 0,399 dengan T-statistik sebesar 10,679 atau T>1,96 dan $\mathrm{p}$ value $=0,000$. Ini mengindikasikan bahwa variabel kepuasan kerja berpengaruh langsung secara positif dan signifikan terhadap variabel OCB pada perawat di rumah sakit umum swasta tipe $\mathrm{C}$ yang ada di 
Kota Denpasar. Hipotesis 4a yang menyatakan bahwa budaya organisasional berpengaruh positif terhadap OCB diterima.

\section{Pengujian Hipotesis $4 \mathrm{~b}$}

Penambahan variabel komitmen organisasional sebagai variabel pemediasi memberikan hasil bahwa kepuasan kerja berpengaruh positif terhadap komitmen organisasional (koefisien $=0,525 ; \mathrm{p}=0,000$ ) dan komitmen organisasional juga berpengaruh positif terhadap OCB (koefisien=0,291; $\mathrm{p}=0,000$ ). Pengaruh langsung kepuasan kerja terhadap OCB tetap signifikan (koefisien=0,245; $\mathrm{p}=0,000$ ). Koefisien jalur antara variabel kepuasan kerja dengan variabel OCB turun dari 0,399 menjadi 0,245. Pengujian variabel mediasi dengan menggunakan perhitungan nilai Variance Accounted For (VAF) dapat dilihat pada Tabel 14.
Tabel 14 memperlihatkan nilai VAF yang diperoleh pada hubungan tidak langsung variabel kepuasan kerja terhadap OCB melalui komitmen organisasional adalah sebesar $0,276(27,6 \%)$. Hasil ini menunjukkan bahwa variabel komitmen organisasional berperan sebagai pemediasi parsial (partial mediation) hubungan antara komitmen organisasional dan OCB. Hipotesis $3 b$ yang menyatakan komitmen organisasional berpengaruh tidak langsung terhadap OCB melalui komitmen organisasional diterima.

\section{Pengujian Hipotesis 5}

Nilai koefisien jalurantara variabel komitmen organisasional dengan variabel OCB adalah sebesar 0,291 dengan T-statistiksebesar 7,071 atau T>1,96 dan $\mathrm{p}$ value $=0,000$. Ini mengindikasikan bahwa variabel komitmen organisasional berpengaruh

Tabel 14. Hasil Pengujian Pemediasi Komitmen Organisasional Pada Pengaruh Kepuasan Kerja Terhadap OCB

\begin{tabular}{llc}
\hline \multicolumn{1}{c}{ Pengaruh } & \multicolumn{1}{c}{ Hubungan Variabel } & Koefisien \\
\hline Pengaruh Langsung & Kepuasan Kerja-> OCB (tanpa pemediasi) & 0,399 \\
Pengaruh Tidak Langsung & Kepuasan Kerja -> Komitmen Organisasional & 0,525 \\
& Komitmen Organisasional -> OCB & 0,291 \\
& Pengaruh Tidak Langsung = 0,525x0,291 & 0,152 \\
Pengaruh Total & Kepuasan Kerja -> OCB (0,399+0,152) & 0,551 \\
VAF & Pengaruh Tidak Langsung/Pengaruh Total $(0,152 / 0,551)$ & 0,276 \\
Sumber: Hasil pengolahan data penelitian
\end{tabular}

secara positif dan signifikan terhadap variabel OCB pada perawat di rumah sakit umum swasta tipe $\mathrm{C}$ yang ada di Kota Denpasar. Hipotesis 5 yang menyatakan bahwa komitmen organisasional berpengaruh positif terhadap OCB terbukti.

\section{PEMBAHASAN}

\section{Pengaruh Budaya Organisasional Terhadap Komitmen Organisasional}

Terdapat hubungan yang searah antara budaya organisasional dengan komitmen organisasionalyaitu semakin tinggi nilai-nilai budaya yang dimiliki dan dikembangkan pada industri rumah sakit umum swasta tipe $\mathrm{C}$ di Kota Denpasar maka akan semakin tinggi tingkat komitmen organisasional para perawat yang ada pada industri rumah sakit tersebut. Hasil tersebut mengindikasikan bahwa nilai-nilai yang terkandung dalam budaya organisasi mampu memunculkan rasa bangga dan kepercayaan perawat dan meningkatkan keterikatan emosional serta keinginan untuk terus bekerja pada organisasi mereka.Hal ini mengindikasikan meningkatnya komitmen organisasional perawat.

Hasil penelitian ini diperkuat oleh studi Momeni et al. (2012) mengenai pengaruh budaya organisasional terhadap komitmen organisasional, bahwa terdapat hubungan yang signifikan antara semua komponen budaya organisasional yang meliputi adaptibility, involvement, adjustment, mission dan komitmen organisasional.Menurut Antonio dan Miguel (2013), adanya penyesuaian yang lebih baik antara persepsi budaya organisasi dan nilai-nilai yang telah dianut organisasi memiliki hubungan yang positip terhadap komitmen organisasional.Hasil ini juga konsisten dengan hasil penelitian Rahmani et al. (2015) yang melakukan studi mengenai hubungan antara budaya organisasional dan komitmen organisasional pada karyawan beberapa rumah sakit yang berada di wilayah Teheran dan hasil studi Sabri et al. (2011) terhadap tenaga pengajar di berbagai institusi pendidikan tinggi dan universitas di Pakistan, yang menyatakan bahwa budaya organisasional memiliki hubungan positif dan signifikan terhadap komitmen organisasional.

\section{Pengaruh Kepuasan Kerja Terhadap Komitmen Organisasional}

Hubungan antara kepuasan kerja dengan komitmen organisasional menunjukkan hubungan yang searah, yaitu semakin tinggi tingkat kepuasan kerja para perawat pada industri rumah sakit umum 
swasta tipe C di Kota Denpasar maka akan semakin tinggi tingkat komitmen organisasional para perawat yang ada pada industri rumah sakit tersebut dan sebaliknya, semakin rendah tingkat kepuasan kerja para perawat pada industri rumah sakit umum swasta tipe C di Kota Denpasar maka akan semakin rendah tingkat komitmen organisasional para perawat yang ada pada industri rumah sakit umum swasta tipe $\mathrm{C}$ tersebut.

Kepuasan kerja karyawan mampu dibentuk oleh faktor-faktor gaji, pengawasan, pekerjaan itu sendiri, adanya kesempatan untuk berkembang dan kondisi dengan rekan kerja. Penelitian ini memberikan indikasi bahwa tingkat kepuasan perawat di rumah sakit umum swasta tipe C di Kota Denpasar yang tinggimampu memunculkan rasa bangga dan kepercayaan perawat, meningkatkan keterikatan emosional para perawat pada organisasinya serta menimbulkan keinginan yang kuat untuk terus bekerja pada organisasi mereka dan memiliki tanggung jawab yang tinggi untuk tetap bertahan di perusahaan. Komitmen organisasional perawat yang meningkat ditandai dengan meningkatnya rasa bangga telah menjadi bagian dari organisasi, tingginya ikatan emosional perawat terhadap rumah sakit, rendahnya keinginan para perawat untuk keluar meninggalkan rumah sakit tersebut.

Penelitian ini mendukung beberapa hasil penelitian sebelumnya dan konsisten dengan hasil penelitian Azeem (2010) yang menyatakan bahwa kepuasan kerja dan beberapa aspek yang terdapat di dalamnya secara signifikan menjadi prediktor komitmen organisasi. Anari (2012) menyimpulkan adanya hubungan positif yang signifikan antara kepuasan kerja dan komitmen organisasional.

Veličković et al.(2014) dalam penelitiannya pada para perawat di Serbia menghasilkan temuan bahwa kepuasan kerja para perawat secara positif signifikan mempengaruhi komitmen organisasional. Pengaruh Budaya Organisasional Terhadap OCB

Budaya organisasional berpengaruh positif terhadap organizational citizenship behavior (OCB) dan merupakan hubungan yang searah. Hasil tersebut mengindikasikan bahwa tingginya persepsi perawat terhadap nilai-nilai yang terkandung dalam budaya organisasi mampu memunculkan kerelaan para perawat dalam melakukan pekerjaan-pekerjaan di luar deskripsi pekerjaan mereka.Perilaku OCB perawat yang meningkat ditandai dengan meningkatnya perilaku berinisiatif untuk membantu atau menolong rekan kerja secara sukarela, perilaku menjaga hubungan baik dengan rekan kerja agar terhindar dari perselisihan, bersedia menerima apapun yang ditetapkan oleh organisasi meskipun dalam keadaan yang tidak sewajarnya, pengabdian atau dedikasi yang tinggi pada pekerjaan dan keinginan untuk melebihi standar pencapaian dalam setiap aspek, serta bertanggung jawab untuk terlibat, berpartisipasi, dan peduli dalam berbagai kegiatan yang diselenggarakan organisasi.

Hasil penelitian ini mendukung hasil penelitian sebelumnya yang dilakukan oleh Ahmadi (2010) bahwa budaya organisasional yang didasarkan pada hasil studi Hofstede, yang dikategorikan sebagai faktor eksternal pembentuk OCB, memiliki pengaruh penting terhadap OCB karyawan.Erkutlu (2011) menyatakan bahwa budaya organisasi mampu menjelaskan dan memberikan peranan yang penting dalam hubungan antara keadilan organisasi dan OCB dalam suatu organisasi. Mohant dan Rath (2012) yang melakukan penelitian pada tiga bidang organisasi yaitu organisasi manufaktur, perbankan dan teknologi informasi menyatakan bahwa terdapat hubungan yang signifikan antara budaya organisasional dan OCB pada ketiga jenis organisasi tersebut.

\section{Pengaruh Tidak Langsung Budaya Organisasional Terhadap OCB Melalui Komitmen Organisasional}

Komitmen organisasional tidak memberikan pengaruh mediasi terhadap hubungan antara budaya organisasional danorganizational citizenship behavior (OCB). Budaya organisasional hanya berpengaruh langsung terhadap OCB. Kehadiran variabel pemediasi komitmen organisasional justru menurunkan pengaruh budaya organisasional terhadap OCB perawat rumah sakit umum swasta tipe $\mathrm{C}$ di Kota Denpasar. Indikasi bahwa para perawat rumah sakit telah memiliki persepsi yang tinggi terhadap budaya organisasional di tempat mereka bekerja telah mampu meningkatkan OCB para perawat di rumah sakit tersebut.Hasil ini juga secara empirik semakin menunjukkan bahwa sampai saat ini belum ditemukan hasil studi yang mendukung peranan mediasi variabel komitmen organisasional terhadap hubungan antara budaya organisasional dan OCB.

\section{Pengaruh Kepuasan Kerja Terhadap OCB}

Hubungan antara kepuasan kerja dengan OCB merupakan hubungan yang searah, yang berarti semakin tinggi tingkat kepuasan kerja para perawat pada industri rumah sakit umum swasta tipe $\mathrm{C}$ di Kota Denpasar maka akan semakin tinggi OCB para perawat yang ada pada industri rumah sakit tersebut.Hasil penelitian ini mengindikasikan bahwa para perawat di rumah sakit umum swasta tipe $\mathrm{C}$ di 
Kota Denpasar yang mendapatkan kepuasan kerja, akan memunculkan kerelaan mereka dalam melakukan pekerjaan-pekerjaan di luar deskripsi pekerjaannya. Peningkatan nilai OCB para perawat tersebut dapat dilakukan dengan cara meningkatkan kepuasan kerja para perawat tersebut. Hasil ini juga sejalan dengan teori dua faktornya Herzberg, yaitu karyawan yang telah memiliki kepuasan kerja yang tinggi akan mampu mendorong karyawan tersebut untuk meningkatkan kinerja mereka dan akan membawa dampak meningkatnya produktivitas perusahaan.

Hasil ini relevan dengan studi Zeinabadi (2010) bahwa kepuasan kerja intrinsik yang merupakan salah satu faktor kepuasan kerja menurut teori dua faktor Herzberg merupakan variabel yang dominan dan berhubungan signifikan dengan OCB. Islam et al. (2014) menyatakan dalam penelitiannya terhadap karyawan bank di Malaysia bahwa kepuasan kerja karyawan bank berhubungan positif dengan OCB karyawan. Arasli dan Baradarani (2014) menyatakan bahwa kepuasan kerja karyawan lini depan hotel bintang tiga, empat dan lima di Teheran berpengaruh positif terhadap OCB. Rahmani et al. (2014)berpendapat terdapat hubungan positif dan signifikan antara kepuasan kerja para guru yang ada di Indonesia dengan OCB.

Pengaruh Tidak Langsung Kepuasan Kerja Terhadap OCB Melalui Komitmen Organisasional

Kepuasan kerja berpengaruh positif secara tidak langsung terhadap organizational citizenship behavior (OCB) melalui pemediasi parsial komitmen organisasional. Kepuasan kerja masih mampu mempengaruhi OCB para perawat pada industri rumah sakit umum swasta tipe $\mathrm{C}$ di Kota Denpasar dengan atau tanpa adanya variabel komitmen organisasional.Variabel komitmen organisasional tidak perlu terlalu dipaksakan keberadaannya apabila karyawan pada industri rumah sakit tersebut telah memiliki tingkat kepuasan kerja yang tinggi yang mampu memberikan pengaruh yang positif terhadap OCB karyawan. Peran komitmen organisasional diperlukan untuk meningkatkan dan mendorong peranan kepuasan kerja dalam meningkatkan OCB perawat di rumah sakit tersebut. Hasil penelitian ini sedikit berbeda dengan penelitian yang dilakukan oleh Foote and Tang (2008)yang menyatakan bahwa OCB secara signifikan dipengaruhi oleh kepuasan kerja karyawan dan akan semakin meningkat dengan semakin tingginya pengaruh moderasi komitmen organisasi. Pengaruh Komitmen Organisasional Terhadap OCB

Terdapat hubungan yang searah antara komitmen organisasional dengan $\mathrm{OCB}$, yaitu semakin tinggi tingkat komitmen organisasional para perawat pada industri rumah sakit umum swasta tipe $\mathrm{C}$ di Kota Denpasar maka akan semakin tinggi OCB para perawat yang ada pada industri rumah sakit tersebut.Hasil penelitian ini mengindikasikan bahwa para perawat di rumah sakit umum swasta tipe $\mathrm{C}$ di Kota Denpasar yang memiliki komitmen organisasional yang baikakan memunculkan kerelaan mereka serta peran ekstra dalam melakukan pekerjaan-pekerjaan di luar deskripsi pekerjaannya. Peningkatan nilai OCB para perawat tersebut dapat dilakukan dengan cara meningkatkan komitmen organisasional para perawat di rumah sakit umum swasta tipe $\mathrm{C}$ di Kota Denpasar tersebut.

Penelitian ini sejalan dengan hasil penelitian yang telah dilakukan oleh Salehi and Gholtash (2011) yang melakukan studi pada bidang akademis, bahwa komitmen organisasional berpengaruh positif terhadap OCB. Khan dan Rashid (2012)menyatakan bahwa dari beberapa variabel bebas yang digunakan sebagai pembentuk OCB, komitmen organisasional merupakan variabel yang paling berpengaruh dan secara signifikan mampu menjelaskan OCB karyawan. Penelitian Davoudi and Mehdi (2012) terhadap karyawan asuransi di Iran, menunjukkan bahwa affective commitment dan normative commitment memberikan implikasi positif terhadap OCB.

\section{SIMPULAN DAN SARAN}

Hasil analisis dan pembahasan secara keseluruhan pada penelitian ini menunjukkan bahwa budaya organisasional dan kepuasan kerja berpengaruh terhadap komitmen organisasional dan OCB, begitu pula komitmen organisasional berpengaruh terhadap OCB. Variabel budaya organisasional dan kepuasan kerja secara langsung dapat mempengaruhi variabel komitmen organisasional dan OCB.

Saran yang dapat diberikan berdasarkan hasil penelitian manajemen rumah sakit diharapkan memiliki dan mampu menerapkan budaya organisasi yang memberikan kesempatan keterlibatan para perawat yang lebih besar dalam proses perencanaan organisasi dan setiap kegiatan yang diselenggarakan oleh organisasi. Manajemen rumah sakit juga diharapkan memperhatikan faktor-faktor pembentuk dari kepuasan kerja para perawatnya. Sistem penggajian yang baik dan berkeadilan diharapkan menjadi perhatian yang serius dari manajemen rumah sakit. Sistem yang dimaksud adalah adanya kesesuaian penghasilan karyawan dengan beban pekerjaan dan keadilan penghasilan antara karyawan yang memiliki beban pekerjaan yang sama. 


\section{REFERENSI}

Ahmadi, F., 2010. Survey Relationship between OCB and Internal \& External Factors Impact on OCB. European Journal of Social Science 16, 469-486.

Allen, N.J., Meyer, J.P., 1990. The measurement and antecedents of affective, continuance and normative commitment to the organization. Journal of Occupational Psychology 63, 1-18.

Anari, N.N., 2012. Teachers: emotional intelligence, job satisfaction, and organizational commitment. Journal of Workplace Learning24, 256-269.

Antonio, O.-P., Miguel, Á.S.-C., 2013. Impact of perceived corporate culture on organizational commitment. Management Decision51, 1071-1083.

Arasli, H., Baradarani, S., 2014. Role of Job Satisfaction in the relationship of Business Excellence and OCB: Iranian Hospitality Industry. Procedia-Social and Behavioral Sciences 109, 1406-1415.

Arif, A., Chohan, A., 2012. How job Satisfaction is influencing the organizational citizenship behavior (OCB): A study on employees working in banking sector of Pakistan. Interdisciplinary Journal of Contemporary Research in Business 4, 74-88.

Azeem, S.M., 2010. Job satisfaction and organizational commitment among employees in the Sultanate of Oman. Journal of Psychology1, 295-299.

Bolon, D.S., 1997. Organizational citizenship behavior among hospital employees: A multidimensional analysis involving job satisfaction and organizational commitment. Hospital \& Health Services Administration 42, 221-241.

Chahal, H., Mehta, S., 2011. Antecedents and Consequences of Organizational Citizenship Behavior (OCB): A Conceptual Framework in Reference to Health Care Sector. Journal of Services Research10, 25-44.

Darsana, M., 2013. The Influence Of Personality And Organizational Culture On Employee Performance Through Organizational Citizenship Behavior. The International Journal of Management2, 35-42.

Davoudi, M., Mehdi, S., 2012. Organizational commitment and extra-role behaviour: A survey in Iran's Insurance Industry. Journal of Business Systems, Governance \& Ethics 7, 66-75.

Denison, D.R., 1990. Corporate culture and organizational effectiveness. John Wiley \& Sons Corporate, England.
Erkutlu, H., 2011. The moderating role of organizational culture in the relationship between organizational justice and organizational citizenship behaviors. Leadership \& Organization Development Journal 32, 532-554.

Foote, D.A., Tang, T.L.-P., 2008. Job satisfaction and organizational citizenship behavior (OCB). Management Decision46, 933-947.

Hair, J., Hult, T., Ringle, C., Sarstedt, M., 2013. A Primer on Partial Least Squares Structural Equation Modeling (PLS-SEM). Sage, Los Angeles.

Harwiki, W., 2013. The Influence of Servant Leadership on Organization Culture, Organizational Commitment, Organizational Citizenship Behavior and Employees' Performance (Study of Outstanding Cooperatives in East Java Province, Indonesia). Journal of Economics and Behavioral Studies5, 876-885.

Herzberg, F., Mausner, B., Snyderman, B., 1959. The Motivation to Work. Wiley Ltd., New York.

Hofstede, G., Neuijen, B., Ohayv, D.D., Sanders, G., 1990. Measuring organizational cultures: A qualitative and quantitative study across twenty cases. Administrative Science Quarterly35, 286-316.

Huang, C.-C., You, C.-S., Tsai, M.-T., 2012. A multidimensional analysis of ethical climate, job satisfaction, organizational commitment, and organizational citizenship behaviors. Nursing Ethics 19, 513-529.

Hutahayan, B., Astuti, E.S., Raharjo, K., Hamid, D., 2013. The Efect of Transformational Leadership, Organizational Culture, Reward to Organizational Citizenship of Employee Behavior at PT Barata Indonesia (Persero). Interdiciplinary Journal of Contemporary Research in Business5, 466-474.

Islam, T., Khan, S.u.R., Ahmad, U.N.U., Ahmed, I., 2014. Exploring the Relationship Between POS, OLC, Job Satisfaction and OCB. Procedia-Social and Behavioral Sciences 114, 164-169.

Khan, S.K., Rashid, M.Z.A., 2012. The Mediating Effect of Organizational Commitment in the Organizational Culture, Leadership and Organizational Justice Relationship with Organizational Citizenship Behavior: A Study of Academicians in Private Higher Learning Institutions in Malaysia. International Journal of Business and Social Science3, 83-91.

Lévy, L., Montmarquette, C., 2004. Reported job satisfaction: what does it mean? The Journal of Socio-Economics33, 135-151. 
Locke, E.A., 1969. What is job satisfaction? Journal of Organizational Behavior and Human Performance4, 309-336.

Luthans, F., 1998. Organizational Behaviour, 8 Edition. Mc. Graw Hill, New Work.

Meyer, J.P., Allen, N.J., 1991. A three-component conceptualization of organizational commitment. Human Resource Management Review1, 61-89.

Mohant, J., Rath, P., 2012. Can organizational culture be a predictor of organizational citizenship behaviors. International Journal of Innovation, Management and Technology 3, 76-79.

Momeni, M., Amir Babak, M., Saadat, V., 2012. The Relationship between Organizational Culture and Organizational Commitment in Staff Department of General Prosecutors of Tehran. International Journal of Business and Social Science3, 217-221.

Nongo, E.S., Ikyanyon, D.N., 2012. The influence of corporate culture on employee commitment to the organization. International Journal of Business and Management7, 21-28.

Organ, D.W., 1988. Organizational citizenship behavior: The good soldier syndrome. Lexington Books/DC Heath and Com, London.

Pavalache-Ilie, M., 2014. Organizational Citizenship Behaviour, Work Satisfaction and Employees' Personality. Procedia - Social and Behavioral Sciences 127, 489-493.

Rahman, U., Wan Shahrazad Wan, S., Rohany, N., Omar, F., 2014. The Role of Job Satisfaction as Mediator in the Relationship between SelfEfficacy and Organizational Citizenship Behavior among Indonesian Teachers. International Journal of Business and Social Science5, 255-261.

Rahmani, H., Azari, S., Vasokolaee, G.R., Mirghaed, M.T., Raadabadi, M., 2015. Organizational Culture and the Organizational Commitment; Correlational Study in Hospital Staffs. Asian Social Science11, 143-149.

Rehan, M.F., Islam, T., 2013. Relationship between organizational commitment and citizenship behaviours. World Journal of Management and Behavioral Studies1, 24-32.

Robbins, S., Judge, T.A., Millett, B., Boyle, M., 2013. Organisational Behavior. Pearson Higher Education AU, England.

Sabri, P.S.U., Ilyas, M., Amjad, Z., 2011. Organizational Culture and Its Impact on the Job Satisfaction of the University Teachers of Lahore. International Journal of Business and Social Science2, 121-128.
Salehi, M., Gholtash, A., 2011. The relationship between job satisfaction, job burnout and organizational commitment with the organizational citizenship behavior among members of faculty in the Islamic Azad University -first district branches, in order to provide the appropriate model. ProcediaSocial and Behavioral Sciences15, 306-310.

Schein, E.H., 2009. The Corporate Culture Survival Guide. Jossey Bass, San Francisco. Shahzad, F., Luqman, R.A., Khan, A.R., Shabbir, L., 2012. Impact of organizational culture on organizational performance: an overview. Interdisciplinary Journal of Contemporary Research in Business3, 975-985.

Sholihin, M., Ph.D., Ratmono, D., Dr., 2013. Analisis SEM-PLS dengan WarpPLS 3.0 untuk Hubungan Nonlinier dalam Penelitian Sosial dan Bisnis. Penerbit ANDI Yogyakarta, Yogyakarta.

Sjahruddin, H., Sudiro, A., 2013. Organizational Justice, Organizational Commitment and Trust in Manager as predictor of Organizational Citizenship Behavior. Interdiciplinary Journal of Contemporary Research in Business4, 133-141.

Suparjo, Rini, D.P., Rusdarti, 2013. Pengaruh Komitmen Organisasi, Kepuasan Kerja Dan Budaya Organisasi Terhadap Organizational Citizenship Behavior (OCB)(Studi pada PT. Plasa Simpanglima Semarang). Jurnal Ilmiah Dinamika Ekonomi dan Bisnis1, 69-88.

Tolentino, R.C., 2013. Organizational commitment and job performance of the academic and administrative personnel. International Journal of Information Technology and Business Management15, 51-59.

Velièkoviæ, V.M., Višnjiæ, A., Joviæ, S., Raduloviæ, O., Šargiæ, Ė., Mihajloviæ, J., Mladenoviæ, J., 2014. Organizational commitment and job satisfaction among nurses in Serbia: A factor analysis. Nursing Outlook62, 415-427.

Yücel, Ý., 2012. Examining the relationships among job satisfaction, organizational commitment, and turnover intention: an empirical study. International Journal of Business and Management7, 44-58.

Zeinabadi, H., 2010. Job satisfaction and organizational commitment as antecedents of Organizational Citizenship Behavior (OCB) of teachers. Procedia-Social and Behavioral Sciences5, 998-1003. 